\title{
Development of a Potentiometric Flufenamate ISE and its Application to Pharmaceutical and Clinical Analyses
}

\author{
A. O. Santini, H. R. Pezza, J. E. de Oliveira and L. Pezza $\square$
}

Instituto de Química, Universidade Estadual Paulista, CP 355, 14801-970 Araraquara-SP, Brazil

\begin{abstract}
As características, o desempenho e a aplicação de um eletrodo do tipo Pt- $\mathrm{Hg}-\mathrm{Hg}_{2}(\mathrm{FF})_{2}$ - Grafite, $\mathrm{FF}=1$ ón flufenamato, são descritas. O eletrodo responde a FF com sensibilidade de $(-58,601,2) \mathrm{mV}$ década ${ }^{-1}$ no intervalo de 1,0 r $10^{-6}$ - 1,0 r $10^{-2} \mathrm{~mol} \mathrm{~L}^{-1}$, a pH 6,0 - 9,0 e com um limite de detecção de $7,1 \mathrm{r} 10^{-7} \mathrm{~mol} \mathrm{~L}^{-1}$. O eletrodo é de custo relativamente baixo e facilmente construído, apresenta um rápido tempo de resposta (10-25 s) e pode ser usado por um período de 5 meses sem qualquer variação considerável nas suas características de desempenho. O eletrodo proposto mostrou boa seletividade para o íon flufenamato na presença de várias substâncias, bem como na presença de alguns carboxilatos e ânions inorgânicos. O eletrodo foi aplicado com sucesso na determinação de ácido flufenâmico em medicamentos e amostras de soro humano.
\end{abstract}

The characteristics, performance, and application of an electrode, namely, Pt- $\mathrm{Hg}-\mathrm{Hg}_{2}(\mathrm{FF})_{2}-$ Graphite, where FF stands for flufenamate ion, are described. This electrode responds to FF with sensitivity of $(-58.601 .2) \mathrm{mV}_{\text {decade }}{ }^{-1}$ over the range $1.0 \mathrm{r} 10^{-6}-1.0 \mathrm{r} 10^{-2}$

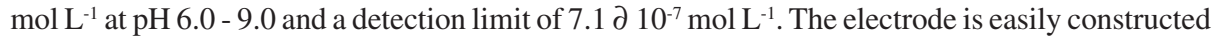
at a relatively low cost with fast response time (within 10-25 s) and can be used for a period of 5 months without any considerable change in its performance characteristics. The proposed electrode displayed good selectivity for flufenamate in the presence of several substances as well as in the presence of some carboxylate and inorganic anions. The electrode was successfully applied to the determination of flufenamic acid in pharmaceuticals and human serum samples.

Keywords: flufenamate-sensitive electrode, potentiometry, dosage forms, blood serum

\section{Introduction}

Flufenamic acid (FFA), [N-(A,A,A-trifluoro-m-tolyl) anthranilic acid] is an analgesic, anti-inflammatory and antipyretic drug. It is extensively used in the treatment of arthritis and other illnesses related to muscular-skeletal problems. ${ }^{1}$ However the use of this drug has been implicated in some cases of nephrotoxicity. ${ }^{2}$ Due to the importance of the assay of FFA for pharmaceutical formulations and biological fluids, several analytical methods have been developed for the quantitative determination of this drug in both pharmaceutical and biological samples.

These methods include spectrophotometry, ${ }^{3-5}$ chromatography, ${ }^{6-11}$ capillary electrophoresis, ${ }^{12,13}$ atomic

*e-mail: pezza@iq.unesp.br absorption spectrometry, ${ }^{14}$ spectrofluorimetry, ${ }^{15-17}$ derivative synchronous fluorescence spectrometry, ${ }^{18}$ high-performance liquid chromatography-mass spectrometry, ${ }^{19}$ flow injection analysis, ${ }^{20}$ and voltammetry. ${ }^{21,22}$ However, many of these methods are often time-consuming, technically demanding and require the use of costly, highly specialized instruments. Thus, there is an important demand for simple, low-cost, sensitive and rapid alternative methods for the determination of FFA in pharmaceuticals and biological fluids.

Potentiometric methods with ion-selective electrodes (ISE's) have proved to be effective for the analysis of pharmaceutical formulations and biological samples, because these sensors offer the advantages of simple design, construction, and manipulation, reasonable selectivity, fast response time, applicability to colored and turbid solutions and possible interfacing with automated and computerized systems. ${ }^{23,24}$ 
To the best of our knowledge, there are a single report on the use of ion-selective potentiometric sensor for the determination of flufenamic acid. ${ }^{25}$ However, this electrode has not been applied for the determination of FFA in pharmaceuticals and biological fluids, thus, precluding the assessment of its usefulness in real analysis.

Previous work from this laboratory dealt with the development of mercury(I)-carboxylate electrodes and their application to solution equilibria, ${ }^{26-29}$ food analysis, ${ }^{30}$ and pharmaceutical analysis ${ }^{31,32}$ involving carboxylate bearing compounds.

The aim of the present contribution was to develop a simple and low-cost potentiometric flufenamate ISE immobilized in a graphite matrix $\left(\mathrm{Pt}-\mathrm{Hg}-\mathrm{Hg}_{2}(\mathrm{FF})_{2}-\right.$ Graphite, where FF stands for flufenamate ion) and to evaluate the applicability of this sensor to the determination of FFA in dosage forms and human serum samples.

\section{Experimental}

\section{Reagents}

High purity deionized water (resistivity $18.2 \mathrm{M} 7 \mathrm{~cm}$ ) obtained by using a Milli-Q Plus system (Millipore Corp., Bedford, MA, USA) was used throughout. All reagents employed were of analytical grade and obtained from E. Merck (Darmstadt, Germany) except flufenamic acid, which was supplied by Sigma (St. Louis, MO, USA).

Sodium flufenamate stock solution was prepared in a manner similar to a previously reported procedure for preparation of sodium naproxenate. ${ }^{33}$ This sodium flufenamate stock solution was analyzed by evaporating and drying to constant weight at $120^{\circ} \mathrm{C}$.

Standardizations of carbonate-free sodium hydroxide, nitric acid and sodium nitrate solutions were performed as described elsewhere. ${ }^{26,31}$ Metallic mercury was purified according to a previously reported procedure. ${ }^{34}$ Mercury (I) flufenamate was prepared by mixing, in aqueous solution, the corresponding nitrate with an excess of sodium flufenamate. The resulting precipitate was filtered through a sintered glass funnel, washed with deionized water until nitrate free, and then dried in a desiccator, over calcium chloride under reduced pressure, at room temperature, to constant mass. A white powder was obtained as the final product.

\section{Electrode preparation and conditioning}

The mercury (I) flufenamate indicator electrode was prepared as follows: mercury (I) flufenamate (1.6 g) and metallic mercury ( $c a .0 .2 \mathrm{~g}$ ) were mixed in an agate mortar and the material was crushed until a homogeneous solid was obtained. Pure powdered graphite $(0.8 \mathrm{~g})$ was then added and the crushing process was continued until perfect homogenization was attained. Part of the resulting solid was transferred to a press mold, being compressed at 8.5 tons for about $5 \mathrm{~min}$. The black pellet (1.6 $\mathrm{mm}$ thick, $12 \mathrm{~mm}$ o.d., and $0.7 \mathrm{~g}$ mass) was fixed at one end of a glass tube $(12 \mathrm{~mm}$ o.d., $80 \mathrm{~mm}$ long) with a silicone-rubber glue ("Rhodiastic", Rhône-Poulenc, France) and allowed to dry for $48 \mathrm{~h}$. Sufficient metallic mercury ( $c a .0 .6 \mathrm{~g}$ ) was then introduced into the tube to produce a small pool on the inner pellet surface; electric contact was established through a platinum wire plunged into the mercury pool and a subsequent conductor cable. Similarly to the previous mercury(I)-carboxylate electrodes reported by the authors ${ }^{30-32}$ this electrode is sealed. This feature, coupled with the small amount of metallic mercury placed inside the electrode ( $c a .0 .6 \mathrm{~g}$ ), stresses that the considered sensor does not offer significant risk to the operator's health and can thus be recognized as safe.

When not in use, the electrode's pellet was kept immersed in a small volume of $0.010 \mathrm{~mol} \mathrm{~L}^{-1}$ sodium flufenamate solution whose ionic strength $(\mu)$ was adjusted to $0.500 \mathrm{~mol} \mathrm{~L}^{-1}$ with a sodium nitrate solution. Before carrying out each experiment, the external surface of the aforementioned pellet was washed with deionized water and dried with absorbent paper.

\section{Instruments}

The electromotive force (emf) values were read to the nearest $0.1 \mathrm{mV}$ with a Metrohm model $692 \mathrm{pH}$ - ion meter (Metrohm Ltd., Herisau, Switzerland).

The reference electrode was a Metrohm $\mathrm{Ag}-\mathrm{AgCl}$ double junction, model 6.0726.100. The $\mathrm{pH}$ of aqueous solutions was adjusted and monitored with the aid of a Metrohm pH electrode, model 6.0234.100. A thermostated titration cell $\left(25.0 \pm 0.1{ }^{\circ} \mathrm{C}\right)$ was employed.

Volume measurements $( \pm 0.001 \mathrm{~mL})$ were performed with a Metrohm model 665 automatic burette.

All experiments were performed in a thermostated room, maintained at $25 \pm 1{ }^{\circ} \mathrm{C}$.

\section{Potentiometric cell}

The following cell was used,

\begin{tabular}{|c|c|c|c|c|}
\hline \multirow{2}{*}{$(-) \mathrm{Ag} \mid \mathrm{AgCl}$} & $\begin{array}{c}{[\mathrm{NaCl}](\mathrm{aq})=} \\
0.010 \mathrm{~mol} \mathrm{~L}^{-1}\end{array}$ & $\begin{array}{c}{\left[\mathrm{NaNO}_{3}\right](\mathrm{aq})=} \\
0.500 \mathrm{~mol} \mathrm{~L}^{-1}\end{array}$ & $\begin{array}{c}{[\mathrm{NaFF}](\mathrm{aq})=} \\
\mathrm{mol} \mathrm{L}^{-1}\end{array}$ & $\begin{array}{c}\text { Graphite } \\
\mathrm{Hg}_{2}(\mathrm{FF})_{2} \mid \\
\mathrm{Hg} \mid \mathrm{Pt}(+)\end{array}$ \\
\hline & $\begin{array}{c}{\left[\mathrm{NaNO}_{3}\right](\mathrm{aq})=} \\
0.490 \mathrm{~mol} \mathrm{~L}^{-1}\end{array}$ & & $\begin{array}{c}{\left[\mathrm{NaNO}_{3}\right](\mathrm{aq})=} \\
(0.500-\mathrm{x}) \mathrm{mol} \mathrm{L}^{-1}\end{array}$ & \\
\hline
\end{tabular}


where FF stands for flufenamate ion and $\mathrm{x}$ was in the range $10^{-1}-10^{-7} \mathrm{~mol} \mathrm{~L} \mathrm{~L}^{-1}$. The ionic strength of the cell compartments was kept constant at $0.500 \mathrm{~mol} \mathrm{~L}^{-1}$. The outer compartment of the reference electrode was refilled periodically with fresh $\mathrm{NaNO}_{3}$ solution.

The performance of the mercury (I) flufenamate electrode was assessed by measuring the emf of the aforementioned cell for $10^{-1}$ to $10^{-7} \mathrm{~mol} \mathrm{~L}^{-1}$ sodium flufenamate solutions. These solutions were freshly prepared by serial dilution of a $0.100 \mathrm{~mol} \mathrm{~L}^{-1}$ stock standard solution with deionized water, at constant $\mathrm{pH}(8.0 \pm 0.1)$ and $\mu$ adjusted to $0.500 \mathrm{~mol} \mathrm{~L}^{-1}$ with $\mathrm{NaNO}_{3}$. The emf readings were obtained for solutions under stirring and recorded when they became stable. A typical calibration plot of the electrode is shown in Figure 1.

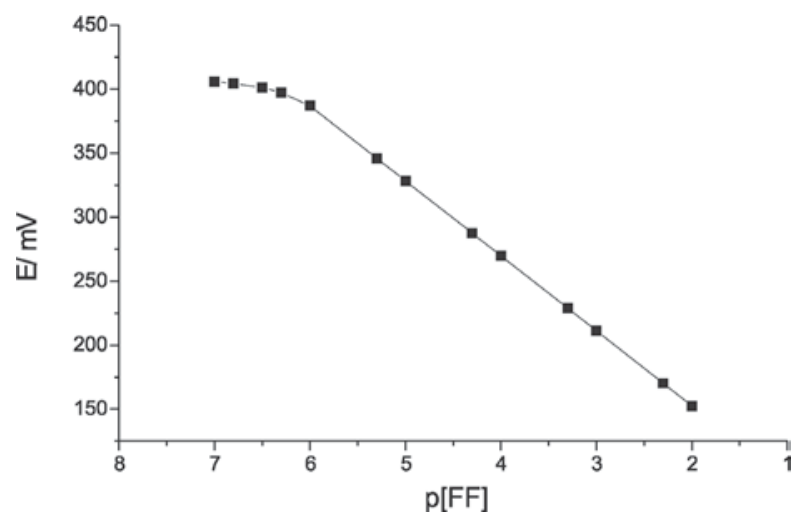

Figure 1. Calibration graph for the proposed flufenamate-sensitive electrode ( $\mathrm{pH}=8.0, \mu 0.500 \mathrm{~mol} \mathrm{~L}^{-1}$ adjusted with $\mathrm{NaNO}_{3}, \mathrm{~T}=25^{\circ} \mathrm{C}$ ).

\section{Determination of flufenamic acid in dosage forms}

The analyzed products were purchased locally from manipulation drugstores or directly from the manufacturers and all were tested prior to the listed expiration date. Four pharmaceutical formulations containing FFA and other components were analyzed with the flufenamate-sensitive electrode.

Representative samples of finely ground tablets or opened capsules containing a quantity equivalent to about $30 \mathrm{mg}$ of FFA was accurately weighed and placed in a glass vessel; $70 \mathrm{~mL}$ of water was added and magnetically stirred for $10 \mathrm{~min}$. The resulting mixture was filtered and its ionic strength was adjusted to $0.500 \mathrm{~mol} \mathrm{~L}^{-1}$ with $\mathrm{NaNO}_{3}$ and the $\mathrm{pH}$ to $8.0 \pm 0.1$ with $10^{-2} \mathrm{~mol} \mathrm{~L}-1 \mathrm{NaOH}$ or $10^{-2} \mathrm{~mol} \mathrm{~L}^{-1} \mathrm{HNO}_{3}$ before volume completion. The resulting solution was quantitatively transferred to a $100 \mathrm{~mL}$ volumetric flask using deionized water (with $\mathrm{pH}$ adjusted to $8.0 \pm 0.1$ ) for rinsing and volume completion. An aliquot of $20 \mathrm{~mL}$ is employed for analysis with the flufenamate-sensitive electrode.

\section{Determination of flufenamic acid in human serum samples}

Drug-free human serum used in this study was obtained from healthy volunteers. The serum was kept in a freezer until analysis.

The extraction procedure of FFA used here was similar to reported procedure by Cerretani et al. ${ }^{7}$ To $5 \mathrm{~mL}$ of spiked human serum with different quantities of FFA, $5 \mathrm{~mL}$ of $1 \mathrm{~mol} \mathrm{~L}^{-1}$ phosphoric acid was added and mixed for $60 \mathrm{~s}$. The samples were then extracted with $6 \mathrm{~mL}$ of dichloromethane, vortex mixed for $5 \mathrm{~min}$ and centrifuged at $10.000 \mathrm{rpm}(8500 \times \mathrm{g})$ for $3 \mathrm{~min}$. The organic phase was then transferred to an appropriate flask and evaporated to dryness under a gentle $\mathrm{N}_{2}$ stream, at $40{ }^{\circ} \mathrm{C}$. The residue was dissolved in $10 \mathrm{~mL}$ of $0.500 \mathrm{~mol} \mathrm{~L}^{-1} \mathrm{NaNO}_{3}(\mathrm{pH}=8.0 \pm 0.1)$ and an aliquot of $8 \mathrm{~mL}$ of reconstituent was employed for analysis with the flufenamate-sensitive electrode using the standard additions method (multiple addition method).

\section{Results and Discussion}

\section{Electrode response}

Experiments carried out as described in "Potentiometric Cell" led to the following linear relationship between the measured emf (E, in $\mathrm{mV})$ and flufenamate ion concentration:

$\mathrm{E}=\mathrm{E}^{0}-\mathrm{S} \log [\mathrm{FF}]$

where $\mathrm{E}^{0}$ is the formal cell potential and $\mathrm{S}$ represents the Nernst coefficient $\left(59.16 \mathrm{mV}\right.$ decade $^{-1}$, at $25{ }^{\circ} \mathrm{C}$, for monovalent ions). Potentiometric parameters and other features associated with the mercury (I) flufenamate electrode are given in Table 1. The above calibration equation and the slope value (Table 1) show that the electrode provides a near-Nernstian response to the flufenamate ion in the range of $10^{-2}$ to $10^{-6} \mathrm{~mol} \mathrm{~L}^{-1}$. The limit of detection, as determined from the intersection of the two extrapolated segments of the calibration graph (Figure 1), was $7.1 \times 10^{-7} \mathrm{~mol} \mathrm{~L}^{-1} .^{35}$ The electrode response displayed good stability and repeatability over the tests; the last mentioned feature is illustrated by the standard deviation values shown in Table 1.

\section{Response time and lifetime of the electrode}

For analytical applications, the response time of an electrode is an important factor. The response time of the electrode was tested by measuring the time required to achieve a steady state potential (within $\pm 0.2 \mathrm{mV} \mathrm{min}^{-1}$ ), for $10^{-2}$ to $10^{-6} \mathrm{~mol} \mathrm{~L}^{-1}$ sodium flufenamate solutions at $\mathrm{pH}$ 8.0. ${ }^{35,36}$ The electrode yielded steady potentials within 10 to 
Table 1. Potentiometric response characteristics of the Mercury (I) flufenamate electrode ${ }^{\mathrm{a}}$

\begin{tabular}{cccc}
\hline Slope $/(\mathrm{mV} \mathrm{decade})^{-1}$ & Intercept, $\mathrm{E}^{0} /(\mathrm{mV})^{\mathrm{b}}$ & Linear range / $\left(\mathrm{mol} \mathrm{L}^{-1}\right)$ & Detection limit / $\left(\mathrm{mol} \mathrm{L}^{-1}\right)$ \\
\hline-58.601 .2 & 35.401 .2 & $1.0 \mathrm{r} 10^{-6}-1.0 \mathrm{r} 10^{-2}$ & $7.1 \mathrm{r} 10^{-7}$ \\
\hline
\end{tabular}

${ }^{\mathrm{a}} \mathrm{T}=25.0 \circ 0.1{ }^{\circ} \mathrm{C} ; \mathrm{pH}=8.0 \circ 0.1 ; \mu 0.500 \mathrm{~mol} \mathrm{~L}^{-1}\left(\mathrm{NaNO}_{3}\right) .{ }^{\mathrm{b}}$ Average value $\pm \mathrm{SD}$ of 35 determinations over a period of $5 \mathrm{months}$. Number of data points: 20-25. Mean linear correlation coefficient: 0.996 o 0.004.

$15 \mathrm{~s}$ at high concentrations $\left(\mathrm{q} 10^{-3} \mathrm{~mol} \mathrm{~L}^{-1}\right)$ and about $25 \mathrm{~s}$ at concentrations near the detection limit. The lifetime of the electrode was found to be 5 months. During this period, the electrode did not show any significant change in working concentration range, slope and response time.

\section{pH Effect}

The influence of $\mathrm{pH}$ on the electrode response was tested over the $\mathrm{pH}$ range 4.0-10.0 for $1.00 \times 10^{-3}$ and 1.00 $\times 10^{-4} \mathrm{~mol} \mathrm{~L}^{-1}$ flufenamate ion concentrations. The resulting solutions' $\mathrm{pH}(\mathrm{s})$ were adjusted with diluted $\mathrm{HNO}_{3}$ or $\mathrm{NaOH}$ solutions.

For $\mathrm{pH}$ values below 6.0, significant fractions of flufenamate ion $(\mathrm{pKa}=4.27)^{37}$ changes to the corresponding protonated form which is not detected by the electrode. For $\mathrm{pH}>9.0$, the hydroxide ion interferes with the electrode's response (Figure 2). The emf values are independent of $\mathrm{pH}$ in the range 6.0-9.0; this can be taken as the working $\mathrm{pH}$ range of the electrode.

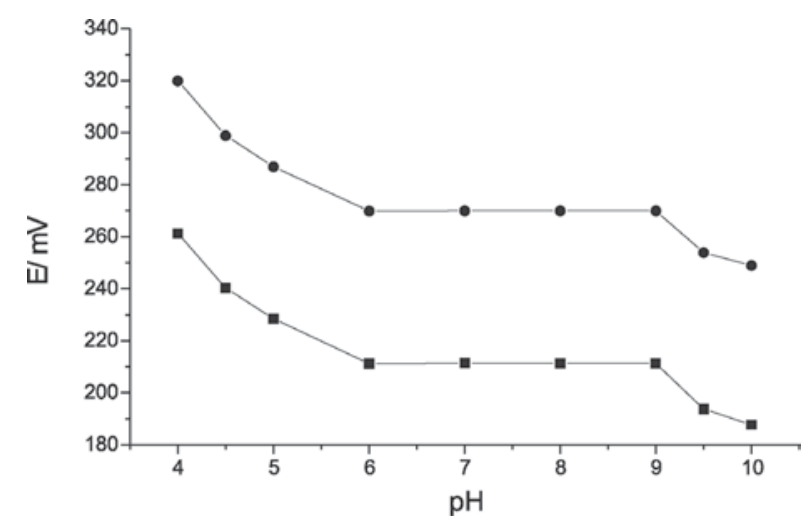

Figure 2. Effect of $\mathrm{pH}$ on the electrode's response at: (ם) $1.0 \mathrm{r} 10^{-3} \mathrm{~mol} \mathrm{~L}^{-1}$ $\mathrm{FF},(\bullet) 1.0 \mathrm{r} 10^{-4} \mathrm{~mol} \mathrm{~L}-1 \mathrm{FF} ; \mu 0.500 \mathrm{~mol} \mathrm{~L}^{-1}$ adjusted with $\mathrm{NaNO}_{3}$, $\mathrm{T}=25^{\circ} \mathrm{C}$.

\section{Electrode selectivity}

The most important characteristic of any ion-selective electrode is its response to the primary ion in the presence of other ions present in solution, which is expressed in terms of the potentiometric selectivity coefficient. The potentiometric selectivity coefficients for the mercury(I) flufenamate electrode $\left(\mathrm{K}_{\mathrm{FF}, \mathrm{M}}\right)$ were determined, for a number of anions
(M), by the matched potential method (MPM) ${ }^{38-40}$ In this method, the selectivity coefficient is defined by the ratio of the activity of the primary ion relative to an interfering ion, when they generate identical potentials in the same reference solution. In the MPM method, both monovalent and divalent ions are treated in the same manner and the valence of the ions does not influence the selectivity coefficient. Furthermore, the MPM can be used with no regard to the electrode slopes being Nernstian or even linear. ${ }^{41}$ Mainly for these reasons, it has increased in popularity in the last few years. ${ }^{42}$

The MPM-selectivity coefficients $\left(\mathrm{K}_{\mathrm{FF}, \mathrm{M}}\right)$ were determined under the following conditions: Initial reference solution ( $\mathrm{pH}=8.0$ ) contains $0.500 \mathrm{~mol} \mathrm{~L}^{-1} \mathrm{NaNO}_{3}$ as a supporting electrolyte and $1.0 \times 10^{-5} \mathrm{~mol} \mathrm{~L}^{-1}$ of the primary ion (flufenamate). The selectivity coefficients were calculated from the concentration of the interfering ion $(\mathrm{M})$, which induced the same amount of the potential change $(\$ e m f=15.0 \mathrm{mV})$ as that induced by increasing the concentration of primary ion. The resulting values of $\mathrm{K}_{\mathrm{FF}, \mathrm{M}}$ are presented in Table 2.

Table 2. Selectivity coefficients $\left(\mathrm{K}_{\mathrm{FF}, \mathrm{M}}\right)$ for various anions $\mathrm{a}^{\mathrm{a}}$

\begin{tabular}{cl}
\hline Anion & $\mathrm{K}_{\mathrm{FF}, \mathrm{M}}$ \\
\hline Formate & $1.3 \times 10^{-4}$ \\
Acetate & $1.8 \times 10^{-3}$ \\
Propionate & $2.1 \times 10^{-3}$ \\
Citrate & $2.9 \times 10^{-3}$ \\
Lactate & $3.2 \times 10^{-3}$ \\
Tartrate & $2.7 \times 10^{-3}$ \\
Benzoate & $3.3 \times 10^{-3}$ \\
Salicylate & $3.1 \times 10^{-3}$ \\
Phthalate & $3.5 \times 10^{-3}$ \\
Oxalate & $2.2 \times 10^{-3}$ \\
Chloride & $2.3 \times 10^{-1}$ \\
Sulphate & $4.3 \times 10^{-4}$ \\
Borate & $5.2 \times 10^{-4}$ \\
Perchlorate & $7.4 \mathrm{r} 10^{-6}$ \\
Nitrate & $8.2 \times 10^{-6}$
\end{tabular}

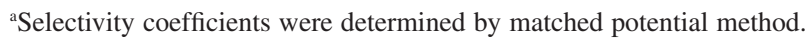
See subsection "Electrode selectivity" for details.

The results comprised in the aforementioned Table 2 show that the selectivity of the mercury(I) flufenamate 
electrode towards all tested organic acid anions is good. No interference was noted for most of the common excipients used in commercial formulations (tablets and capsules) such glucose, lactose, starch, sodium glycolate, magnesium stearate, hydroxypropylmethylcellulose, microcrystalline cellulose, croscarmellose sodium, titanium dioxide, silicon dioxide, povidone, polyethyleneglycol, hypromellose, methylcellulose, vanillin.

Sulphate and borate have a low selectivity coefficient (Table 2); Nitrate and perchlorate have a very low selectivity coefficient and they can therefore be used as background electrolytes or ionic strength adjusters for flufenamate solutions before performing potentiometric measurements.

Some interference by chloride ion might be expected as shown in Table 2. In the dosage forms analyzed in this work (tablets and capsules), chloride ion is seldom found and hence the proposed sensor can be used for direct determination of FFA in these samples without previous extraction procedures. Concerning the human serum samples analyzed by the potentiometric electrode, it should be noted that analytical procedure adopted in this work is based on dichloromethane extraction of FFA from acidified biological matrices followed by its reversion to the aqueous phase $\left(0.500 \mathrm{~mol} \mathrm{~L}^{-1} \mathrm{NaNO}_{3(\mathrm{aq})} ; \mathrm{pH}=\right.$ $8.0 \pm 0.1$ ) as flufenamate ion. The chloride content found in the last mentioned aqueous phase (which originates from the analyses of human blood serum) was always $<1 \mu \mathrm{g} \mathrm{L}^{-1}$, as analyzed by the mercury thiocyanate method. ${ }^{43}$ Therefore, the working procedure removes chloride interference.

\section{Analytical application}

In order to test the analytical applicability of the proposed electrode, it has been applied for the determina- tion of FFA in dosage forms and human serum samples using a standard additions method (multiple addition method). ${ }^{44,45}$

Table 3 shows statistical analysis of the results obtained by using the presently proposed flufenamate-sensitive electrode and the official method of B.P (non-aqueous alkalimetry) ${ }^{46}$ for FFA determination in certain dosage forms. In all cases, the calculated $\mathrm{F}$ and $t$ values did not exceed the theoretical values, indicating that there is no significant difference between the performance of the two methods as regard accuracy ( $t$-test) and precision ( $F$-test).

Flufenamic acid is readily absorbed after oral ingestion and a peak plasma (or serum)concentration occurs about 2 h. ${ }^{47} \mathrm{FFA}$ is given orally in doses of 200-1000 mg daily; this leads to a final blood concentration of $c a$. 4-20 $\mu \mathrm{g} \mathrm{mL}-1 .{ }^{47}$ In humans, FFA is mainly metabolized into acyl glucuronides. ${ }^{48-50}$ Taking into account the role of the flufenamate ion in the electrode response, along with the very low concentration of glucuronides in serum, ${ }^{49,50}$ no interference from these metabolites is expected in the determination of FFA in human blood serum by the proposed electrode.

Experiments were performed to determine the feasibility of using the flufenamate-sensitive electrode for determination of FFA in human serum samples. Serum samples previously spiked with $4,8,12,16$ and $20 \mu \mathrm{g}$ $\mathrm{mL}^{-1}$ of FFA were treated and analyzed as described under "Determination of Flufenamic Acid in Human Serum Samples". The concentrations of FFA were selected from pharmacokinetic data of this compound. ${ }^{51}$ The recovery values found by application of the proposed potentiometric sensor and the comparative HPLC method ${ }^{52}$ are given in Table 4. Satisfactory recovery values were

Table 3. Determination of flufenamic acid in commercial formulations

\begin{tabular}{|c|c|c|c|c|c|}
\hline Product (laboratory) & Label to content ${ }^{\mathrm{b}}$ & $\begin{array}{c}\text { Electrode } \\
\text { Found }^{\mathrm{c}} /\left(\mathrm{mg} \mathrm{unit}^{-1}\right)\end{array}$ & $\begin{array}{c}\text { Method } \\
\operatorname{RSD}^{\mathrm{e}} /(\%)(\mathrm{n}=6)\end{array}$ & $\begin{array}{c}\text { B.P. method }{ }^{46} \\
\left.\text { Found }^{\mathrm{c}} / \text { (mg unit }^{-1}\right)\end{array}$ & $\mathrm{RSD}^{\mathrm{e}} /(\%)(\mathrm{n}=6)$ \\
\hline \multicolumn{6}{|l|}{ Capsules } \\
\hline A (Alexandria) & 100 & $\begin{array}{c}98.1 \pm 1.6 \\
\mathrm{t}^{\mathrm{d}}=1.17, \mathrm{~F}^{\mathrm{d}}=2.42\end{array}$ & 1.6 & $97.8 \pm 1.8$ & 1.8 \\
\hline B (Parke Davis) & 100 & $\begin{array}{c}99.1 \pm 1.8 \\
\mathrm{t}^{\mathrm{d}}=1.13, \mathrm{~F}^{\mathrm{d}}=2.74\end{array}$ & 1.8 & $99.4 \pm 2.1$ & 1.9 \\
\hline \multicolumn{6}{|l|}{ Tablets } \\
\hline $\begin{array}{l}\mathrm{C} \text { (Manipulation } \\
\text { drugstore) }\end{array}$ & 50 & $\begin{array}{c}50.7 \pm 1.2 \\
\mathrm{t}^{\mathrm{d}}=1.18, \mathrm{~F}^{\mathrm{d}}=2.88\end{array}$ & 1.9 & $51.2 \pm 1.1$ & 2.1 \\
\hline $\begin{array}{l}\text { D (Manipulation } \\
\text { drugstore) }\end{array}$ & 75 & $\begin{array}{c}74.7 \pm 1.5 \\
\mathrm{t}^{\mathrm{d}}=1.16, \mathrm{~F}^{\mathrm{d}}=2.35\end{array}$ & 2.1 & $74.1 \pm 1.3$ & 1.7 \\
\hline
\end{tabular}

${ }^{a}$ These contain some or all of the following substances/materials: glucose, lactose, starch, sodium glycolate, magnesium stearate, hydroxypropylmethylcellulose, microcrystalline cellulose, croscarmellose sodium, titanium dioxide, silicon dioxide, povidone, polyethyleneglycol, hypromellose, methylcellulose, vanillin. ${ }^{b}$ Declared concentration of flufenamic acid in $\mathrm{mg} \mathrm{unit}^{-1}$. ${ }^{\mathrm{c}}$ Values found are the average of six independent analyses $(\mathrm{n}=6) \pm$ the corresponding standard deviation (SD). Expressed as flufenamic acid. ${ }^{\mathrm{d}}$ Values of $t$ and $F$ at $95 \%$ confidence level. Theoretical values: $t=2.23, F=5.05$. ${ }^{e}$ Relative standard deviation (RSD). 
Table 4. Determination of flufenamic acid added to human serum samples

\begin{tabular}{|c|c|c|c|c|}
\hline $\begin{array}{l}\text { FFA added to blood } \\
\text { serum }^{\mathrm{a}} /\left(\mathrm{Mg} \mathrm{mL}^{-1}\right)\end{array}$ & $\begin{array}{c}\text { Electrode } \\
\text { Found }^{\mathrm{b}} /\left(\mathrm{Mg} \mathrm{mL}^{-1}\right)\end{array}$ & $\begin{array}{c}\text { Method } \\
\text { Recovery / (\%) }\end{array}$ & $\begin{array}{c}\text { Comparative } \\
\text { Found }^{\mathrm{b}} /\left(\mathrm{Mg} \mathrm{mL}^{-1}\right)\end{array}$ & $\begin{array}{c}\text { Method }{ }^{52} \\
\text { Recovery / (\%) }\end{array}$ \\
\hline 4 & $3.9 \pm 0.1$ & 97.5 & $3.9 \pm 0.1$ & 97.5 \\
\hline 8 & $7.9 \pm 0.2$ & 98.7 & $8.1 \pm 0.2$ & 101.2 \\
\hline 12 & $12.2 \pm 0.4$ & 101,7 & $12.1 \pm 0.3$ & 100.8 \\
\hline 16 & $16.2 \pm 0.4$ & 101.2 & $16.1 \pm 0.3$ & 100.6 \\
\hline 20 & $20.3 \pm 0.5$ & 101.5 & $20.2 \pm 0.4$ & 101.0 \\
\hline
\end{tabular}

These concentrations for FFA were selected from pharmacokinetic data. ${ }^{51}$ balues found are the average of six determinations $(\mathrm{n}=6) \pm$ the corresponding standard deviation (SD). Expressed as flufenamic acid.

obtained indicating that the endogenous compounds of serum samples do not interfere in the detection of FFA using the proposed method. Therefore, the proposed electrode can be used for the determination of FFA in dosage forms and human serum samples.

\section{Conclusions}

The results of this study show that the potentiometric method based on flufenamate ion-selective electrode immobilized in a graphite matrix may provide an attractive alternative for the determination of flufenamic acid.

The proposed potentiometric electrode is easy to prepare, exhibits long lifetime, show high sensitivity and wide dynamic range. Good selectivity, very low detection limit, rapid response and low cost make this electrode suitable for analysis of FFA in dosage forms and human serum samples.

\section{Acknowledgments}

We would like to thank FAPESP, CNPq, CAPES and FUNDUNESP Foundations (Brazil), for financial support.

\section{References}

1. Insel, P. A.; The Pharmacological Basis of Therapeutics, MacGraw-Hill: New York, 1996.

2. Knights, K. M.; Tsoutsikos, P.; Miners, J. O.; Expert Opin. Drug Metab. Toxicol. 2005, 1, 399.

3. Mahhrous, M. S.; Abdel-Khalek, M. M.; Abdel-Hamid, M. E.; Talanta 1985, 32, 651

4. Issa, A. S.; Beltagy, Y. A.; Kassem, M. G.; Daabees, H. G.; Talanta 1985, 32, 209.

5. Khier, A. A.; Analyst 1987, 112, 1399.

6. Mikami, E.; Goto, T.; Ohno, T.; Matsumoto, H.; Inagaki, K.; Ishihara, H.; Nishida, M.; J.Chromatogr., B 2000, 1, 81.

7. Cerretani, D.; Micheli, L.; Fiaschi, A. I.; Giorgi, G.; J.Chromatogr., B 1996, 678, 365.
8. Shimada, K.; Nakajim, M.; Wakabayashi, H.; Yamato, S.; Bunseki Kagaku 1989, 38, 632.

9. Papadoyannis, I. N.; Zotou, A. C.; Samanidou, V. F.; J. Liq. Chromatogr. 1992, 15, 1923.

10. Shinozuka, T.; Takei, S.; Kuroda, N.; Kuhira, K.; Yanagida, J.; Eisei Kagaku 1991, 37, 461.

11. Jagota, N. K.; Stewart, J. T.; J.Chromatogr., A 1992, 604, 255.

12. Ruiz, T. P.; J.Chromatogr., B 1998, 708, 249.

13. Polasek, M.; Pospisilova, M.; Urbanek, M.; J. Pharm. Biomed. Anal. 2000, 23, 135.

14. Salem, H.; Kheir, A. A.; Anal. Lett. 1995, 28, 1833.

15. de la Peña, A. M.; Díez, N. M.; Gil, D. B.; Olivieri, A. C.; Escandar, G. M.; Anal. Chim. Acta 2006, 569, 250.

16. de la Peña, A. M.; Mansilla, A. E.; Díez, N. M.; Gil, D. B.; Olivieri, A. C.; Escandar, G. M.; Appl. Spectrosc. 2006, 60, 330.

17. Capitán-Vallvey, L. F.; Navas, N.; del Olmo, M.; Consonni ,V.; Todeschini, R.; Talanta 2000, 52, 1069.

18. Ruiz,T. P.; Lozano, C. M.; Tomás, V.; Carpena, J.; Talanta 1998, $47,537$.

19. Abdel-Hamid, M. E.; Nonotny, L.; Hoda, H.; J. Pharm. Biomed. Anal. 2001, 24, 587.

20. Albero, M. I.; Sanchez-Pedreño, C.; Garcia, M. S.; J. Pharm. Biomed. Anal. 1995, 13, 1113.

21. Garcia, I. A.; Lopez, M. C. B.; Castañon, M. J. L.; Ordieres, A. J. M.; Blanco, P. T.; Electroanalysis 2005, 17, 1555.

22. Sabry, S. M.; Mahgoub, H.; J. Pharm. Biomed. Anal. 1999, 21, 993.

23. Stefan, R. I.; Baiulescu, G. E.; Hassan, Y.; Crit. Rev. Anal. Chem. 1997, 27, 307.

24. Stefan, R. I.; van Staden, J. F.; Aboul-Enein, H. Y.; Electrochemical Sensors in Bioanalysis, Marcel Dekker: New York, 2001.

25. Kiryu, S.; Oda, Y.; Sasaki, M.; Chem. Pharm. Bull. 1983, 31, 1089.

26. Pezza, L.; Molina, M.; Moraes, M.; Melios, C. B.; Tognolli, J. O.; Talanta 1996, 43, 1689.

27. Pezza, L.; Molina, M.; Melios, C. B.; Moraes, M.; Tognolli, J. O.; Talanta 1996, 43, 1697.

28. Pezza, L.; Molina, M.; Melios, C. B.; Moraes, M.; Tognolli, J. O.; Gomes, H. M.; Int. J. Environ. Anal. Chem. 1997, 68, 295. 
29. Cavalheiro, A. C. V.; Moraes, M.; Pezza, L.; Ecl. Quim. 2000, $25,123$.

30. Pezza, L.; Santini, A. O.; Pezza, H. R.; Melios, C. B.; Ferreira, V. J. F.; Nasser, A. L. M.; Anal.Chim. Acta 2001, 433, 281.

31. Peres, A. M.; Moraes, M.; Pezza, L.; Pezza, H. R.; Melios, C. B.; Microchem. J. 1998, 60, 184.

32. Ferreira V. J. F.; Cavalheiro, A. C. V.; Fagnani, E.; Moraes, M.; Pezza, L.; Pezza, H. R.; Melios, C. B.; Anal. Sci. 1999, 15, 249.

33. Valsami, G. N.; Machera, P. E.; Koupparis, M. A.; Analyst 1989, $114,387$.

34. Freiser, H.; Ion-Selective Electrodes in Analytical Chemistry, Plenum Press: New York, 1978.

35. Buck, R. P., Lindner, E.; Pure Appl. Chem. 1994, 66, 2527.

36. Uemasu, I.; Umezawa,Y.; Anal.Chem. 1982, 54, 1198.

37. Zhou, C.; Jin, Y.; Kenseth, J. R.; Stella, M.; Wehmeyer, K. R.; Heineman, W. R.; J. Pharm. Sci. 2005, 94, 576.

38. Gadzekpo, V. P. Y.; Christian, G. D.; Anal. Chim. Acta 1984, $164,279$.

39. Christian, G. D.; Analyst 1994, 119, 2309.

40. Umezawa, Y.; Umezawa, K.; Sato, H.; Pure Appl. Chem. 1995, 67, 507.

41. Bakker, E.; Bühlmann, P.; Pretsch, E.; Chem. Rev. 1997, 97, 3083.
42. Mazloum, M.; Amini, M. K.; Baltork, I. M.; Sens. Actuators, B 2000, 63, 80 .

43. William, W. J.; Handbook of Anion Determination, Butterworths: London, 1979.

44. Bader, O. M.; J. Chem. Educ. 1980, 57, 703.

45. Li, G.; Polk, B. J.; Meazell, L. A.; Hatchett, D. W.; J. Chem. Educ. 2000, 77, 1049.

46. British Pharmacopoeia, HMSO, 1988.

47. Reynold, J.E. F.; The Extra Pharmacopoeia, The Pharmaceutical Press: London, 1996.

48. Mcgurk, K. M.; Remmel, R. P.; Hosagrahara, V. P.; Tosh, D.; Burchell, B.; Drug Metab. Dispos. 1996, 24, 842.

49. Spahn-Lannguth, H.; Benet, L. Z.; Drug Metab. Rev. 1992, 24, 5.

50. Ioannou; P. C.; Rusakova, N. V.; Andrikopoulou, D. A.; Glynou, K. M.; Tzompanaki, G. M.; Analyst 1998, 123, 2839.

51. Moffat, A. C.; Clarke's Isolation and Identification of Drugs in Pharmaceutics, Body Fluids, and Post-Mortem Material, The Pharmaceutical Press: London, 1986.

52. Dannhardt, G.; Laufer, S.; Lehr, M.; Clin. Chem. 1988, 34, 2580.

Received: May 22, 2007

Published on the web: January 30, 2008

FAPESP helped in meeting the publication costs of this article. 